\title{
To Green or Not to Green: A Political, Economic and Social Analysis for the Past Failure of Green Logistics
}

\author{
Matthias Klumpp ${ }^{1,2}$ \\ 1 Department of Industrial Engineering and Business Information Systems (IEBIS), \\ University of Twente, Drienerlolaan 5, 7522 NB Enschede, The Netherlands \\ 2 Institute for Logistics and Service Management, FOM University of Applied Sciences, \\ Leimkugelstr. 6, 45141 Essen, Germany; matthias.klumpp@fom.de; Tel.: +49-201-81004-554 \\ Academic Editors: Russell G Thompson and Benjamin T. Hazen \\ Received: 13 February 2016; Accepted: 26 April 2016; Published: 4 May 2016
}

\begin{abstract}
The objective of green logistics has thus far failed. For example, the share of greenhouse gas emissions by the transportation and logistics sector in Europe rose from 16.6\% in 1990 to $24.3 \%$ in 2012 . This article analyzes the reasons behind this failure by drawing on political, economic and business as well as social motivations and examples. At the core of this analysis are the established theorems of the Jevons paradox and the median voter (Black, Downs) in combination with time-distorted preferences of voters and consumers. Adding to the hurdles of green logistics are the problems of short-term political programs and decisions versus long-term business investments in transportation and logistics. Two cases from Germany are outlined regarding this political "meddling through" with a recent 2015 truck toll decision and the support for electric trucks and vehicles. Finally, the article proposes two ways forward: public control and restriction of carbon raw materials (coal, oil), as well as public investment in low-emission transport infrastructure or biofuels as the more feasible and likely alternative.
\end{abstract}

Keywords: Jevons paradox; median voter; time-distorted preferences; green transportation technology; e-vehicles; truck toll system

\section{Introduction}

The claim for an increased level of sustainability in all areas of society has remained unchallenged since its introduction into scientific literature by the German Carl von Clausewitz in 1713 regarding a sustainable management of forest areas ("Nachhaltigkeit" [1]). Even more emphasis was placed on the concept in milestone publications including the "Limits of Growth" by the Club of Rome [2-5] and the Brundtlandt report with its modern-day definition of sustainability [6,7]. Today, the triple-bottom-line-approach focusing on economic, ecological and social implications and interaction areas is widespread and academically accepted as the main route towards improved sustainability [8-12].

For the area of logistics and transportation, this approach is appropriate, even though expressions such as "green logistics" or "green transportation" seem to place more impetus on the ecological ("green") dimension [13-16]. Nevertheless, concepts regarding improving the sustainability-i.e., "greening" - of logistics and supply chains around the globe do adhere to the three impact areas. However, for the sake of argument, the main analysis in this article is directed towards the ecological question of reduced energy demand as well as emission output by all transportation, warehousing and other logistics activities. It must be noted however, that especially the social dimension of logistics activities should be the focus for sustainability research, given the fact that labor conditions as well as worker migration and increased customer awareness in Europe and elsewhere place new social burdens and responsibilities on the logistics industry. 
This contribution is structured as follows: Section 2 provides a short status report regarding the developments and achievements of green logistics in the past up until the current state; Section 3 describes the main hope of technology improvement for increased sustainability in logistics, especially propulsion technologies and energy concepts for transportation; Section 4 outlines why technological improvement and efficiency gains have not brought about an increased level of sustainability in logistics, using an extended analytical concept of the Jevons paradox. The political and social level is addressed in Section 5 in order to further explain the present failure of green logistics objectives. In order to remedy this failure, Section 6 outlines two possible advances towards a worthwhile implementation of green logistics for the future. The last section then provides a short conclusion and outlook.

\section{History and Status Quo}

The objective of green logistics in terms of reduced energy consumption as well as emissions has not been successful within the European Union (EU-28); the share of greenhouse gas (GHG) emissions caused by the transportation and logistics sector has risen from 16.6\% in 1990 to $24.3 \%$ in 2012 [17]. In total absolute emissions, this means an increase from 962.6 to 1173.3 million tons of $\mathrm{CO}_{2}$ equivalents per annum (in itself an increase of $21.89 \%$, or roughly $1 \%$ per year) as outlined in Table 1 .

Table 1. GHG emissions from transportation in Europe in millions of tons (EU-28), [17].

\begin{tabular}{cccccc}
\hline Year & Aviation (Civil) & Road & Rail $^{\mathbf{1}}$ & Navigation & Total $^{2}$ \\
\hline 1990 & 84.1 & 722.4 & 13.5 & 133.1 & 962.6 \\
1991 & 82.3 & 730.7 & 12.2 & 132.3 & 966.9 \\
1992 & 88.3 & 755.4 & 12.0 & 133.9 & 998.2 \\
1993 & 92.1 & 761.6 & 11.4 & 136.2 & 1009.7 \\
1994 & 95.5 & 768.8 & 10.9 & 133.0 & 1016.5 \\
1995 & 101.3 & 782.7 & 10.6 & 133.1 & 1036.2 \\
1996 & 106.8 & 806.4 & 10.4 & 141.3 & 1073.2 \\
1997 & 111.8 & 819.4 & 10.1 & 150.0 & 1099.5 \\
1998 & 120.0 & 845.6 & 9.8 & 156.5 & 1140.3 \\
1999 & 129.1 & 863.6 & 9.4 & 150.1 & 1161.0 \\
2000 & 135.8 & 859.5 & 9.5 & 154.7 & 1168.6 \\
2001 & 133.7 & 874.9 & 8.8 & 161.2 & 1187.5 \\
2002 & 130.2 & 886.7 & 8.7 & 164.7 & 1199.4 \\
2003 & 134.3 & 897.0 & 8.6 & 168.9 & 1217.9 \\
2004 & 144.2 & 914.6 & 8.6 & 178.0 & 1255.0 \\
2005 & 151.6 & 912.7 & 8.0 & 187.4 & 1270.0 \\
2006 & 157.5 & 919.4 & 7.9 & 197.0 & 1292.6 \\
2007 & 162.0 & 931.3 & 8.2 & 199.1 & 1310.6 \\
2008 & 162.2 & 909.0 & 8.0 & 196.7 & 1287.5 \\
2009 & 150.3 & 886.9 & 7.3 & 179.8 & 1234.0 \\
2010 & 149.7 & 883.0 & 7.3 & 175.0 & 1224.5 \\
2011 & 153.3 & 875.1 & 7.4 & 178.0 & 1223.2 \\
2012 & 150.7 & 843.2 & 7.1 & 162.8 & 1173.3 \\
\hline
\end{tabular}

${ }^{1}$ Excluding indirect emissions from electricity consumption, therefore largely underestimated. ${ }^{2}$ Including a small part of "other" transportation emissions such as those from pipelines etc.--therefore not the exact sum of the previous four columns.

Usually, for all reported data, the transportation sector includes passenger transport as well as cargo transport. Roughly half of the emissions are caused solely by cargo transport, though the overall trend towards an increase is similar in passenger transport. It is argued here that similar mechanisms as outlined below for cargo transport are also at play in the passenger transport sector.

Similarly, all relevant numbers have not been reduced as advertised (see Table 1). A slight but recognizable downturn of consumption and emissions was experienced during the 2007-2009 global economic crisis due to a sharp decline in transportation demand. Interestingly, as experienced 
by many logistics companies, this recession decline started earlier compared to other economic indicators, contributing to the inclination of transportation as an "early-warning indicator" of economic downturns as companies, for example, stop ordering new materials or making investments before reducing production output and cutting back in other corporate decision areas such as labor and research and development. Moreover, although 2012 saw a small decline, recent data for 2013 and 2014 shows that this is not a trend change but a sign that traffic has been on the rise: For Germany, the internal (national) cargo traffic increased from 633.2 billion tonkilometers (in 2012) to 646.0 (2013) and 654.6 tonkilometers in 2014 [18] (p. 245), a further 3.38\% increase in two years. The international cargo traffic into and out of Germany increased from 196.3 billion tonkilometers in 2012 to 201.7 in 2014 [18] (p. 183), an increase of $2.75 \%$ in the two years.

Furthermore, despite only carrying a small share of total weight and volume, the transport mode with the largest increases over the last 25 years has been the air cargo sector, as seen below in Figure 1 (EU-28). This has severe implications, as this sector has not only the highest energy consumption as well as emission levels per tonkilometer, but is also thought to have an even higher environmental impact regarding climate change due to very high emissions during flight. (For the shipping sector, on the other hand, the carbon emissions are discussed in terms of impact on sea level and they are less severe or can even positive, partly due to cloud formation at a high or low altitude; this additional dynamic is referred to as "radiative forcing" (RF) impact, see [19] (p. 331).)

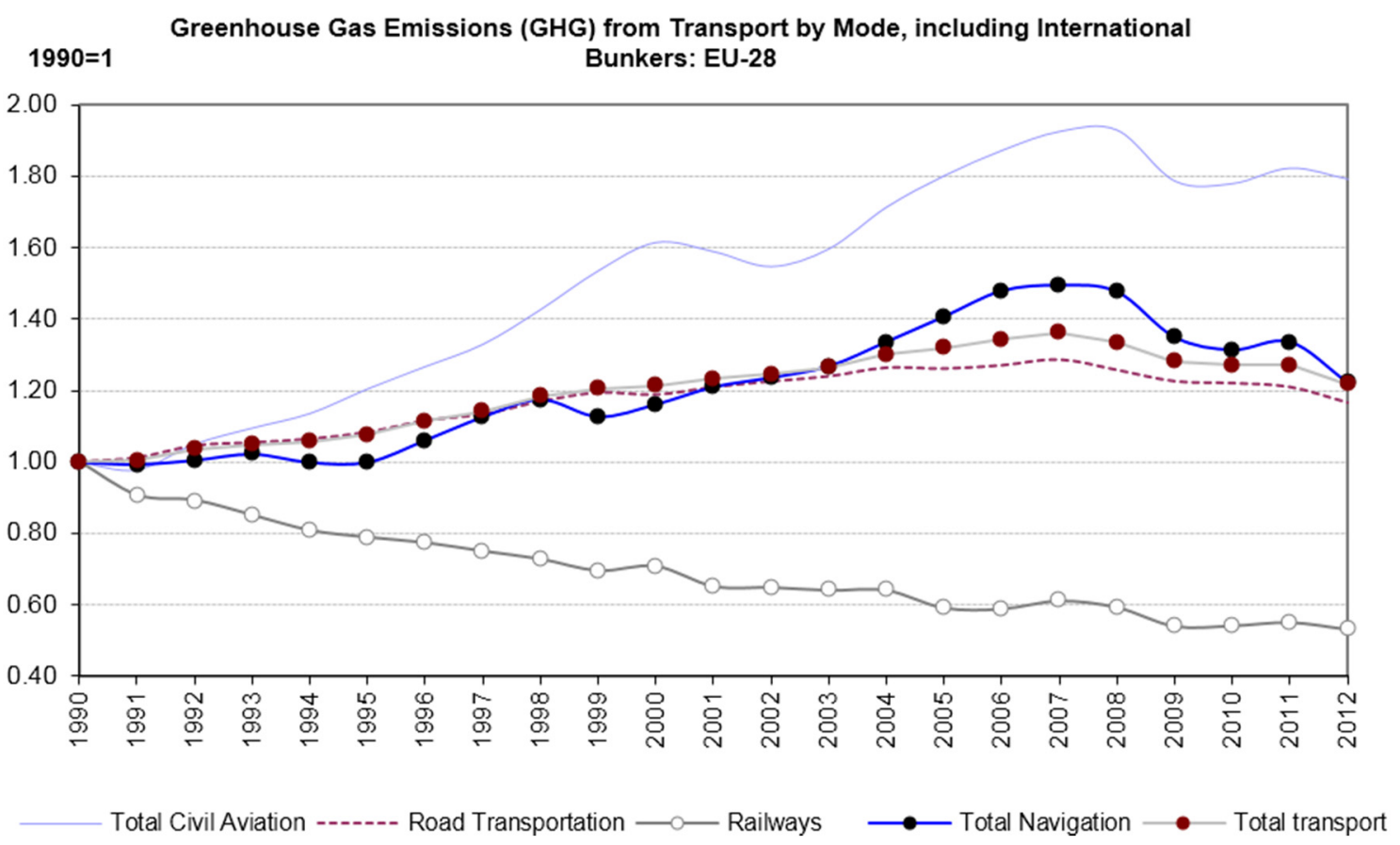

Figure 1. Development of GHG emission shares by transport modes in the EU (index) [17].

These numbers represent the historic development and status quo for Europe, but other countries and regions in the world are faring no better: For the US, development is shown in Figure 2 with a similar picture of a significant overall increase of GHG emissions from the transportation sector, halted only during the global recession of 2007-2009.

This leads to the historic as well as problematic development that the transportation sector is the only economic sector with a long-term increase of GHG emissions, whereas other sectors such as industry, private residents, as well as the energy sector have a reduction in their absolute emission levels. This is depicted in Figure 3 for Europe (1990 to 2012).

For global developments, it has to be kept in mind that Europe may be one of the larger economic regions and therefore also of energy consumers as well as GHG emitters (accounting for about $12 \%$ of 
GHG emissions 1990-2011, after the USA with 16\% and China with 15\%, [20]). Nevertheless, the energy consumption as well as the emission levels per GDP output are relatively low or efficient as shown in Figure 4. Other countries including China, Russia, Canada or also Indonesia have much higher levels of emissions per GDP than Europe, Japan or India. This indicates that the global problem and especially the further development on a global scale may be even more problem-ridden than illustrated by the more prominent European perspective and numbers.

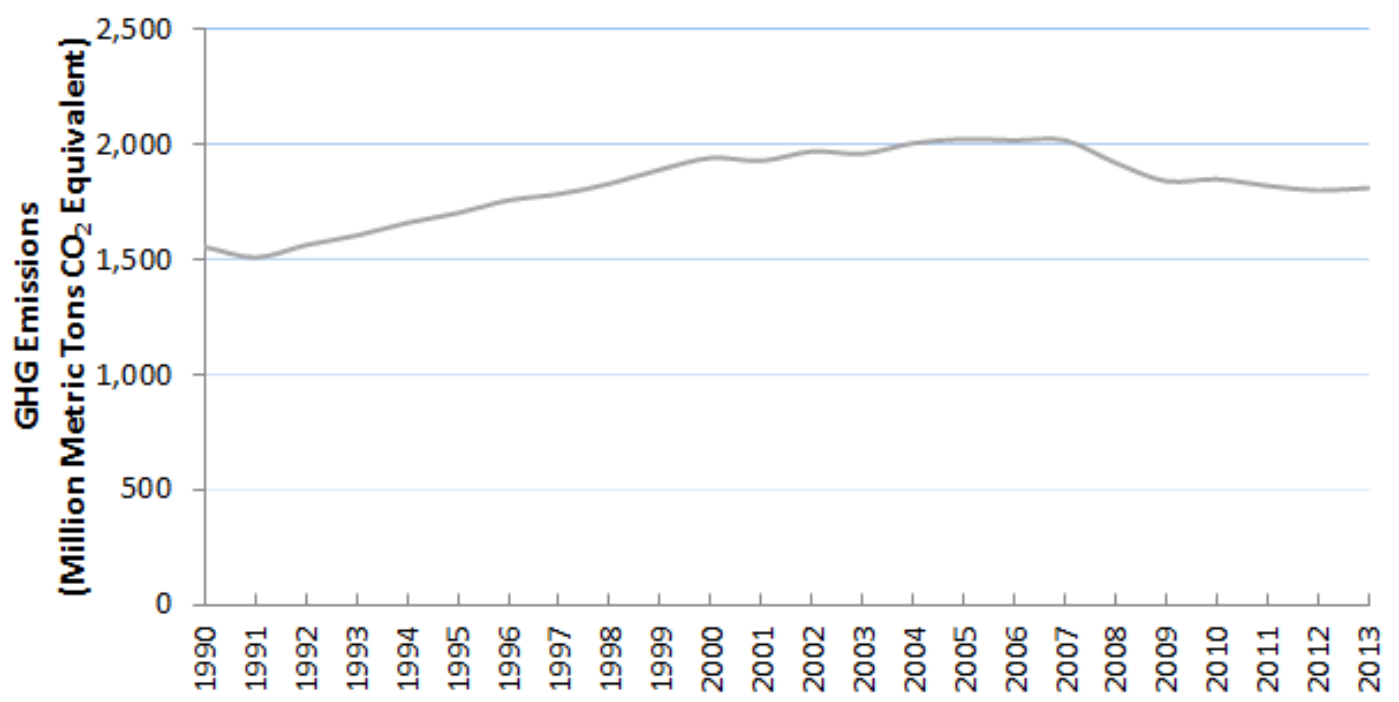

Figure 2. Development of GHG Emissions by the Transportation Sector in the USA (1990-2013) [21].

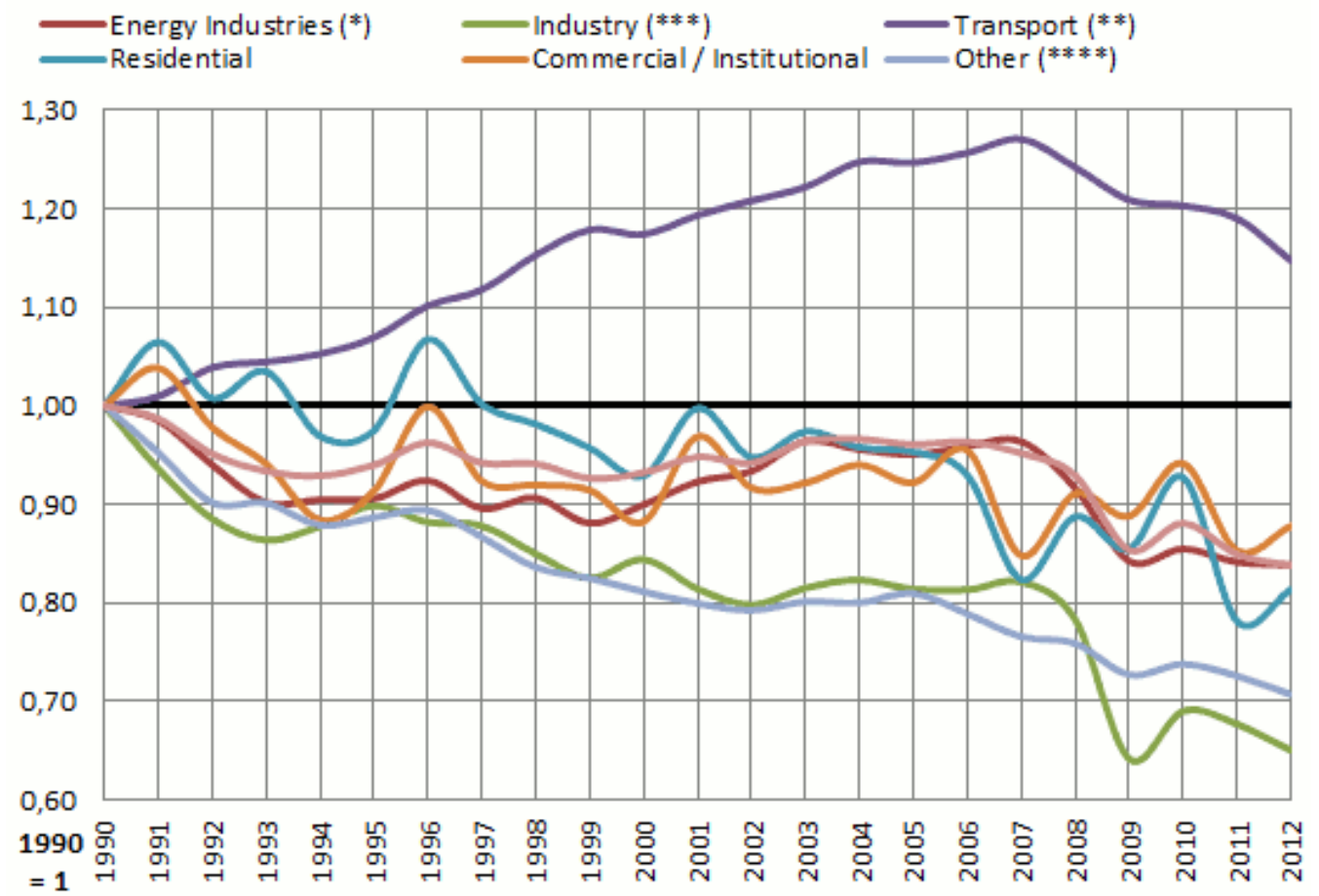

Figure 3. Development of GHG emission shares by sectors in the EU-28 (1990-2012; $1990=1)$ [22]. Notes: $\left(^{*}\right)$ Excluding LULUCF (Land Use, Land-Use Change and Forestry) emissions and International Bunkers; $\left(^{* *}\right)$ Excluding International Bunkers (international traffic departing from the EU); ${ }^{* * *}$ ) Emissions from Manufacturing and Construction and Industrial Processes; ${ }^{* * * *}$ ) Emissions from Fuel Combustion in Agriculture/Forestry/Fisheries, Other (Not specified), Fugitive Emissions from Fuels, Solvent and Other Product Use, Waste, Other. 
1200

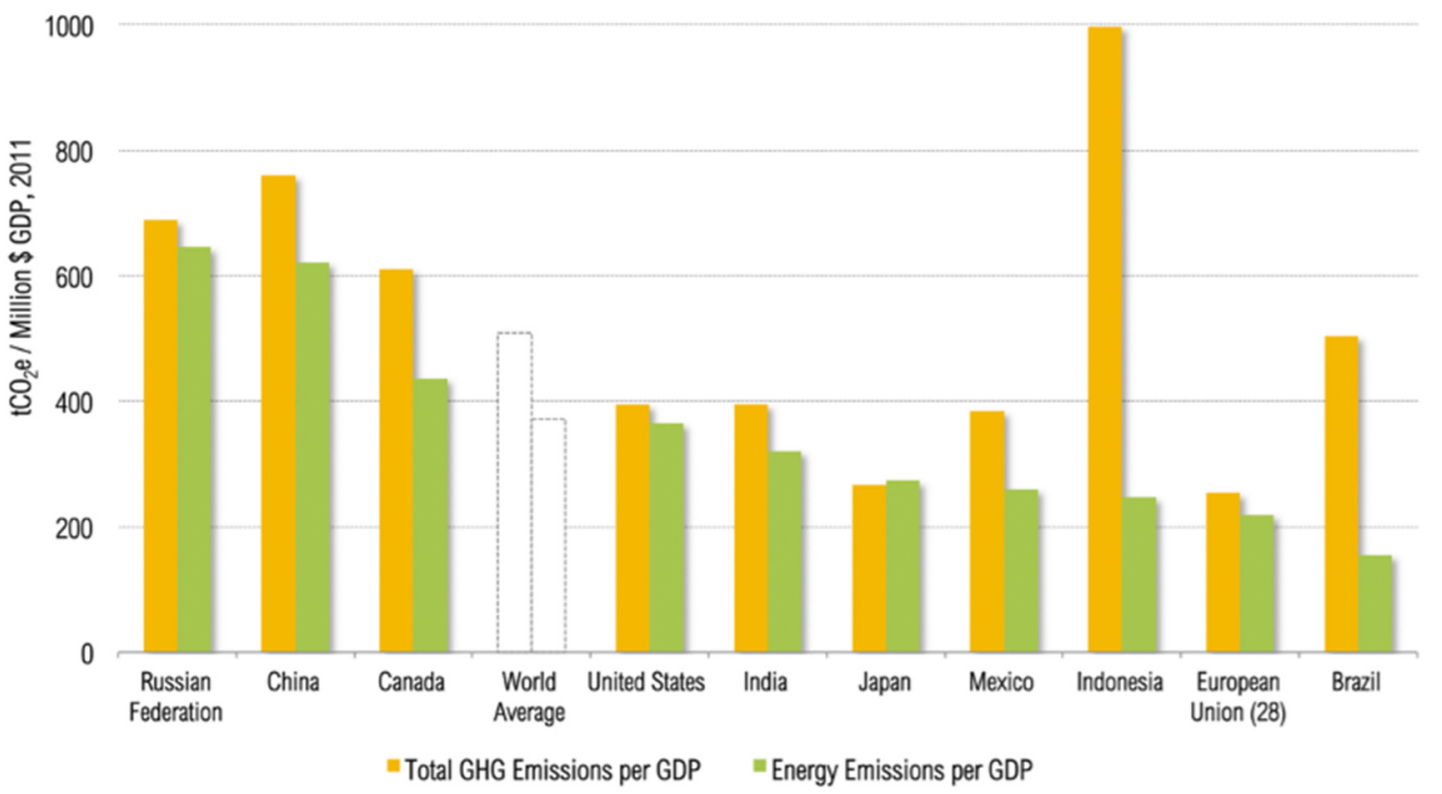

Figure 4. Relation of GHG emissions to GDP per country [20].

Therefore, it can be concluded that the overall "mission" of green logistics and green transportation-reducing the energy consumption as well as the GHG emissions from logistics and transportation-has so far been a failure. Moreover, the prospects of a quickly approaching turning point are not imminent, especially with the increased economic development of larger parts of the world community, even if ethically and socially more than justified. Consequently, overall energy consumption and GHG emission levels in the transportation sector are likely to rise further.

This increase is in spite of the fact that-besides the quantitative numbers-the societal and corporate acceptance of the overall sustainability concept for logistics is assumed to be a given, though major concerns for e.g., customer acceptance [23,24], reach (i.e., for governmental as well as non-governmental non-profit organizations, see $[25,26])$, as well as control and monitoring $[15,27,28]$ resume. Still, the described research question of why the concept of green and sustainable logistics failed in general, especially regarding emissions impact, remains open; but before diving deeper into it we must take a look in Section 3 at the technology development, which for many actors is the main source of hope for successful green logistics.

\section{Technology in Road Transportation and Green Logistics}

Usually one of the most encouraging areas for green logistics is development in technology; the hope is to provide more transportation with less energy consumption and emission volumes. For example, the Intergovernmental Panel on Climate Change (IPCC) reports a high expectation towards such technology-based efficiency gains for GHG emission reduction in transportation:

"The mitigation potential by 2030 for the transport sector is estimated to be about 1600-2550 Mt $\mathrm{CO}_{2}(\ldots)$. This is only a partial assessment, based on biofuel use throughout the transport sector and efficiency improvements in light-duty vehicles and aircraft and does not cover the potential for heavy-duty vehicles, rail transport, shipping, and modal split change and public transport promotion and is therefore an underestimation" [19] (p. 326). (The report itself warns consecutively: "This estimate of mitigation costs and potential is highly uncertain. (... ) low agreement, limited evidence" [19] (p. 326)). 
The part of this estimate regarding biofuels has clearly been unrealistic: biofuel use has never really met the reduction expectations for logistics and transportation due to different contributing factors and obstacles [29-32] (Although the life-cycle assessment (LCA) GHG emission potential is being discussed here, some studies posited a reduction of $80 \%$ while others only $40 \%$ ). Moreover, the current downward trend of the oil price will economically prohibit any further use of biofuels:

"The World Bank is lowering its 2016 forecast for crude oil prices to $\$ 37$ per barrel in its latest Commodity Markets Outlook report from $\$ 51$ per barrel in its October projections. The lower forecast reflects a number of supply and demand factors. These include sooner-than-anticipated resumption of exports by the Islamic Republic of Iran, greater resilience in U.S. production due to cost cuts and efficiency gains, a mild winter in the Northern Hemisphere, and weak growth prospects in major emerging market economies. Oil prices fell by 47 percent in 2015 and are expected to decline, on an annual average, by another 27 percent in 2016" [33].

This downward trend started in mid-2014 when the raw oil price already halved from around US $\$ 100$ to about US $\$ 50$ per barrel (see Figure 5). This specific trend-if continued as forecasted by the World Bank-will singlehandedly prohibit many political measures to curb GHG emissions. This will especially be the case in the transport sector as the drop in oil and diesel prices, the major cost factor, will in turn increase demand for transportation services, ultimately leading to increased GHG emissions.

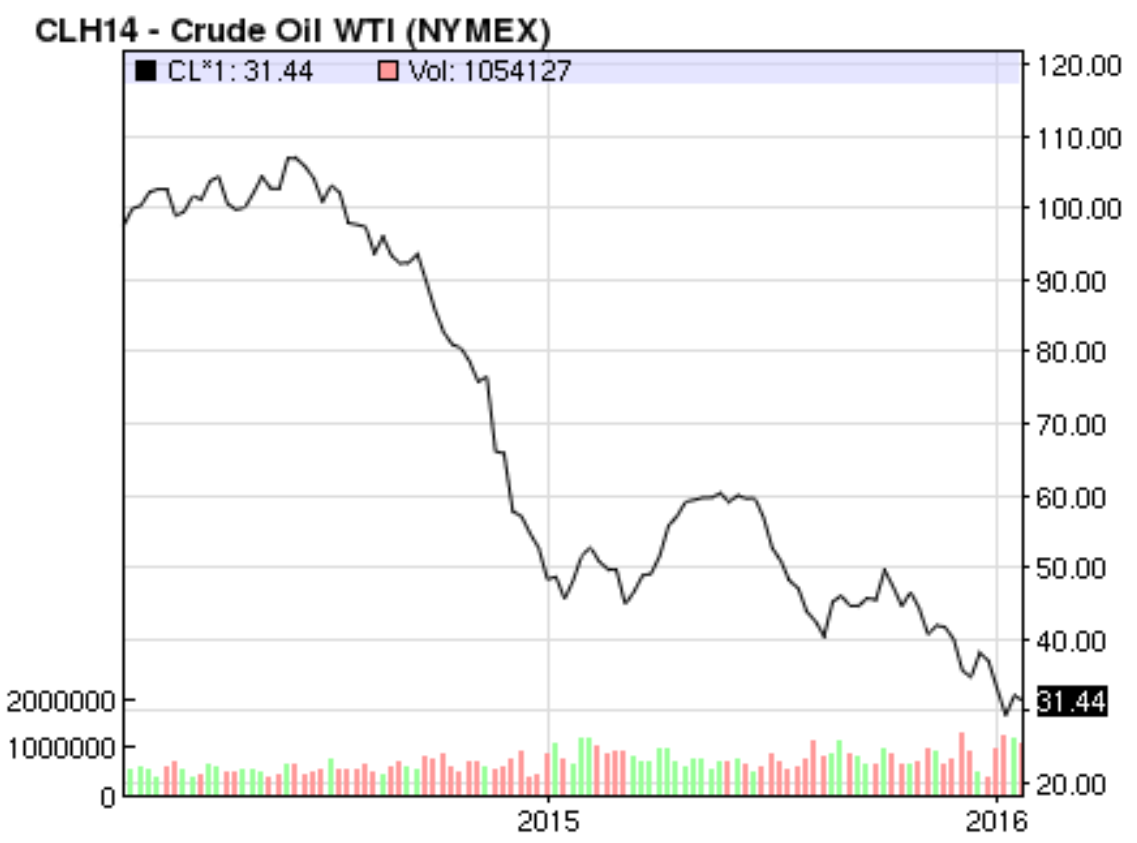

Figure 5. Trading chart; 24 months of crude oil trading in US \$ (WTI, NASDAQ) [34].

We must therefore examine in the next section the real efficiency gains by technology improvement for road transportation over the last few years as the main hope for a significant GHG emission reduction in transportation.

\subsection{The Efficiency Advance in Diesel Engines for Trucks}

In recent decades, there has been a significant reduction of average diesel fuel consumption i.e., with trucks. Whereas the average consumption per 100 kilometers for heavy-duty (HD) trucks reached about $50 \mathrm{~L}$ of diesel during the 1960s, during the rising oil prices of the 1970s, the average consumption fell to the level of about $40 \mathrm{~L}$. Again, during the first half of the 1980s, average consumption of HD trucks further decreased to about 35 L [35]. In the last 30 years, though, there has been no 
significant further reduction of average consumption; there were even smaller increases due to newly introduced emission limits (i.e., $\mathrm{NO}_{\mathrm{x}}, \mathrm{SO}_{\mathrm{x}}$ ), where, in order to fulfill these regulations, increased burning temperatures as well as artificial after-burner technologies had to be engaged, thereby slightly increasing consumption [36]. (The current levels of specific truck models are depicted in Table A1/Appendix A for more detailed information.) This leads to the assumption that at reasonable operation costs, there may be a physical limit regarding further reductions of diesel consumption for HD trucks. Though many technology and research contributions have theoretically shown further reduction potential in the fields of aerodynamics, powertrains, shifting as well as motor technology and driver training, reaching upwards of a further 60\% [37-40], in real-life business transportation, however, these theoretical values have not been realized in the last 30 years.

Additionally, for further forecast endeavors, it has to be kept in mind that the average age and investment cycle for HD trucks rests between 10 and 15 years depending on the country, and is significantly longer in developing countries. This implies that changes in technology and consumption for new trucks have relevant overall effects on total fleet emissions in operation only with a significant time and volume lag of about 15 years. For example, as illustrated by Table 2,the current fleet mix in Germany of HD trucks in 2015 still has a share of more than 50\% of trucks in lower emission classes than EURO IV (Emission classes for European trucks are regulated by different emission levels over time by the European Commission/EU, see [41] and Table B1/Appendix B.) EURO IV was introduced in 2005, ten years earlier. In short: Emission values for 2050 are already defined by available-and practically also bought by business customers, not only in theory-motor and truck technology.

Table 2. Truck fleet mix regarding emission classes in Germany (1 January 2015) [42] (p. 26).

\begin{tabular}{cccccc}
\hline $\begin{array}{c}\text { No of Trucks per } \\
\text { Weight Class and } \\
\text { Emission Class }\end{array}$ & $\begin{array}{c}\text { EURO VI } \\
\text { (and EEV) }\end{array}$ & EURO V & EURO IV & $\begin{array}{c}\text { Below } \\
\text { EURO IV }\end{array}$ & $\begin{array}{c}\text { Share below } \\
\text { EURO IV }\end{array}$ \\
\hline Truck & 109,285 & 932,922 & 229,403 & $1,325,123$ & $51.03 \%$ \\
Tractor-trailer & 73,407 & 91,210 & 7176 & 125,803 & $42.27 \%$ \\
Total & 182,692 & $1,024,132$ & 236,579 & $1,450,926$ & $50.13 \%$ \\
\hline
\end{tabular}

It also has to be noted that not all improvements are as limited and bleak as those in the consumption and GHG emission case. For instance, regarding noise emissions, huge technology advances were realized in the last decades. As explained by the European Commission in regards to Europe:

"Today, 25 modern trucks make less noise than one built in 1980. Trucks have become much quieter over the last 30 years thanks to such technological innovations as special insulation, low-rolling resistance tyres and other noise control techniques. Further reductions could be made by using low-rolling resistant surfaces for new roads" [43].

Again, however, the time lag problem of investment cycles and usage timelines also applies here; the available technology today does not correspond with the average, overall impact. Technology is therefore a "future option" due to the long investment cycles in transportation-for the transport modes of navigation, rail and air cargo, this is even more severe as investment cycles are much longer. Ships even have cycles up to 50 years.

\subsection{Alternative Propulsion Systems for Green Logistics-An Overview}

As outlined in the previous section, diesel and combustion engines in general are not going to "save the day" in the near future of up to 2050. Therefore, we explore the alternative technologies available for transportation in this timeframe regarding the potential energy and emission reduction from the technology point of view.

To begin, the viable segmentation of three important areas regarding energy use in transportation has to be recognized according to Figure 6: For all means of energy pathways into transportation the 
selection of a primary energy source is necessary, be it fossil or renewable. Second, an energy carrier has to be used, choosing from a variety of options i.e., diesel, gas, synthetic fuel, hydrogen or electricity. Finally, in the third use section, different engine options can be applied (combustion, electric motor with fuel cell or battery) in addition to the unlisted electricity line networks used for railway transportation (electric motor with network supply of electricity) [44]. As Figure 6 outlines, a very high number of combinatory options arises from this distinction—and any informed person may recognize that there will likely be no single solution for all transport modes and applications.

From existing research, it can roughly be deduced that the shorter the transport range, the easier it is to replace combustion engines with electric drives. Conversely, for long-distance transportation, combustion engines with different carrier fuel options will be the mode of choice for a long time to come $[45,46]$. In any case, overall energy consumption as well as GHG emission levels do not so much depend on the second and third stage of the concept, as on the primary energy used. Therefore, a truck system using a combustion engine with synthetic fuel from renewable biomass production may be more sustainable than an electric truck supplied by electricity produced from fossil coal energy.

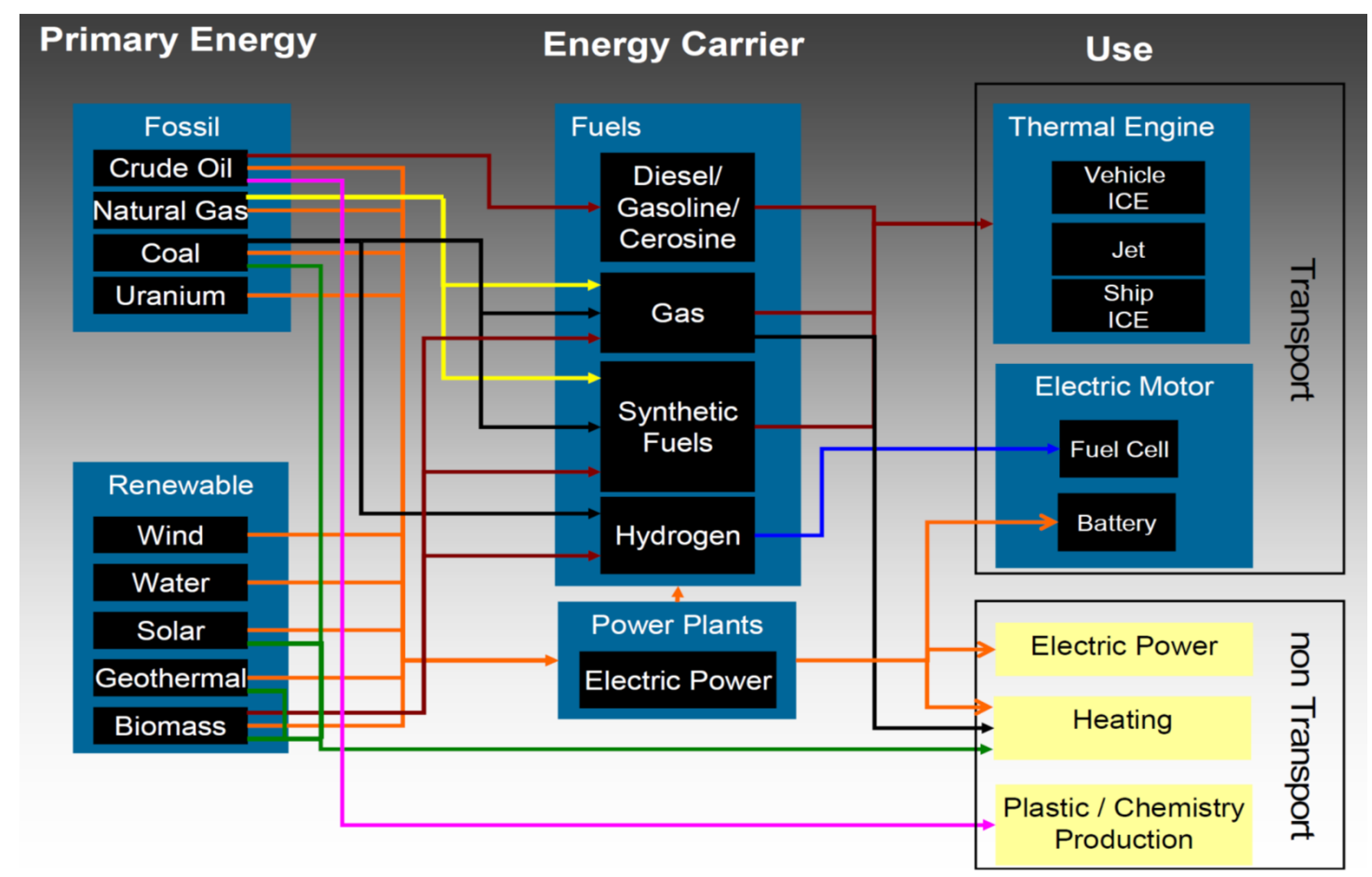

Figure 6. Energy pathways in transportation [44] (p. 11).

This is specifically outlined in Figure 7 below for different propulsion systems based on hydrogen, showing that significant reductions of carbon emissions can be achieved compared to the gasoline combustion engine (index) with a variety of systems as e.g., liquified natural gas (LNG) or electricity supplied by wind or photovoltaic electricity. However, as is indicated by hydrogen production costs, significant investments in the technology and in the upstream energy production in a sustainable fashion are necessary in order to reach this objective. 


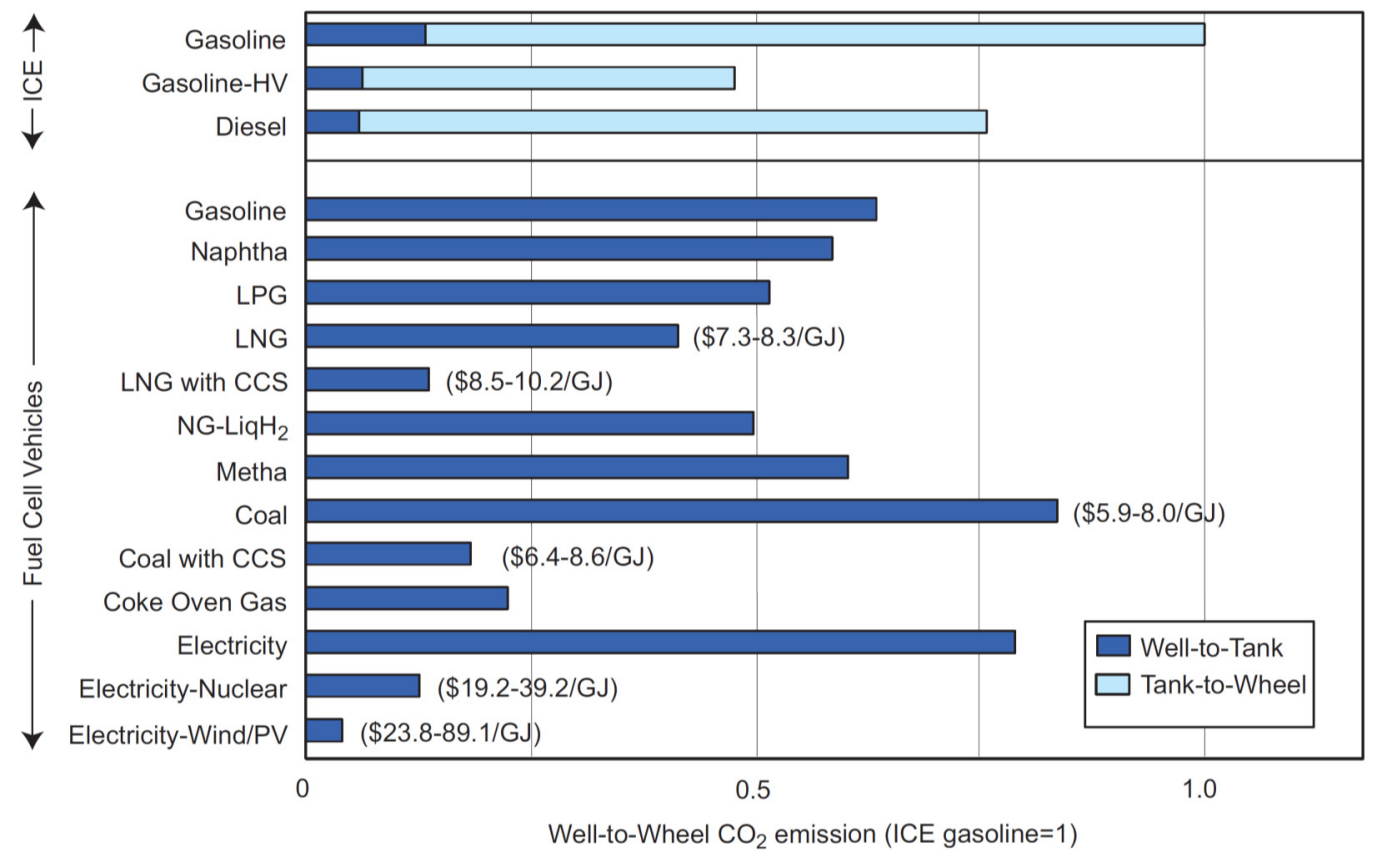

Figure 7. Prognosis for GHG emissions by new propulsion technologies [19] (p. 346).

This still huge investment and technology hurdle for the future development of green logistics and transportation has also been commented on by the European Commission regarding battery technology as follows:

"Greater efforts are needed to increase electro-mobility: today's electric car would need a battery pack weighing 2500 kilos to provide the same energy as a diesel car with a 50-litre tank" [43].

Furthermore, as outlined, some transportation segments like high payload as well as long-distance transport will remain dominated by combustion engines due to physical limitations. Hopefully, however, we will be able to implement more sustainable energy and fuel concepts for these combustion engines in transportation based on renewable primary energy [45,46].

Why there has been no significant reduction in emission levels despite the technology improvements described is the question for the next section regarding the rebound effect.

\section{Jevons Paradox in Green Logistics}

In this section, we want to analyze in detail the technology-economy nexus part of the misshapen development of green logistics. This is implemented on the basis of the well-known Jevons paradox. The first subsection will therefore outline the basic principle of the Jevons paradox paradigm. The second subsection will enlarge the basic theorem with the double nature of logistics in a globalizing world. The third subsection, moreover, will discuss implications of this problem for green logistics.

\subsection{The Basic Jevons Paradox}

Regarding the basic assumptions as outlined by Jevons and other authors [47,48], the starting point of a control circuit as also depicted in Figure 8 is an increased technological efficiency $[49,50]$ (p. 370). In the original contribution and also many following research publications this was addressed towards the use of coal and other energy raw materials [51-54]. Today, also further areas of rebound effects have been described, such as traffic and motorways as well as smaller applications i.e., household electronics, see [55-59]. In Figure 8, this is represented with the "12 o'clock position" in the control circuit. 


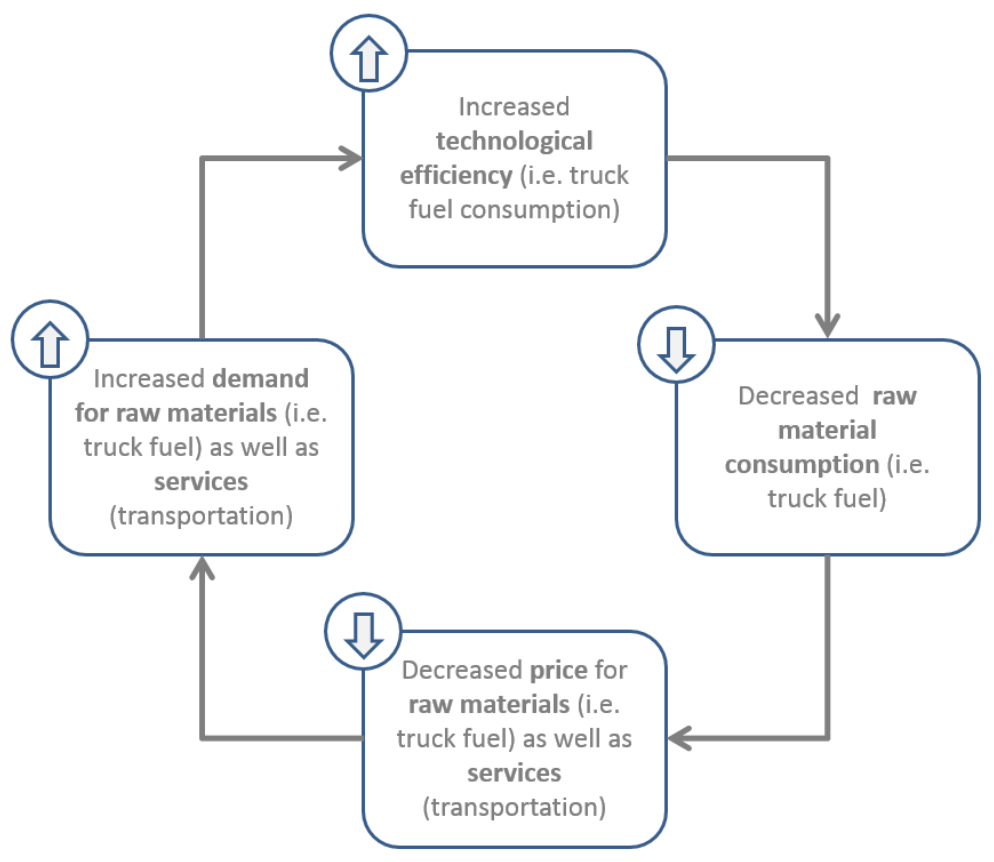

Figure 8. Basic Jevons paradox principle (rebound).

For the case of transportation, as outlined in the previous section in general, the consumption of truck fuel (i.e., diesel) is analyzed and followed up. Regarding road transportation-with similar developments also for rail, ship and air transportation-the subsequent consequence is ceteris paribus a decreased raw material consumption, meaning less diesel usage and demand (" 3 o'clock position").

In an assumed market system, this will lead to a decreased price for those raw materials, i.e., diesel fuel. Though especially in the oil and diesel markets, there are many other forces at play as experienced with the recent steep downturn of prices due to oversupply; this assumption may hold in a ceteris paribus analysis. Interestingly, not only the diesel price would decrease, but also the price for the connected transportation service (road transportation by truck) as diesel is a major cost component for conducting these transportation services (Figure 8, "6 o'clock position").

Finally, this leads to an increased demand for the specific raw materials (diesel) as well as the subsequent transportation services (truck transportation) as shown in the "9 o'clock position" of the above control circuit-leading to the paradoxical sight compared to the initially increased efficiency that overall raw material consumption is rising not falling. And indeed, the increased demand for raw materials will again motivate (cost savings) further technology and efficiency improvements in spite of the decreased raw material prices, closing the control loop as depicted in Figure 8.

Within these dynamics, the theorem is closely linked to other concepts of economic and society dynamics and interaction-for example, the theory of cumulative causation by Myrdal [60,61]. This relates especially to the circular nature also of the Jevons paradox as the described effects are repeating themselves over and over during a cycle of (incrementally) increasing raw material consumption-as described by Myrdal for institutional changes in an interactive economic and society setup. Therefore, similarities occur, but the difference lies in the fact that the Jevons paradox does not incorporate institutional changes and only technology, efficiency and market changes in the described global market setup.

Empirical evidence for the described phenomenon is still lacking, such as for a comparative study of two economies with the distinction of existing and non-existing technological change (efficiency gains). ("Short of studies of two non-trading economies alike in every aspect except technological change, the debate still seems heavily dependent on theory" [50] (p. 19). Though it may be argued that, for example, the development of the two German states (BRD West Germany and DDR East 
Germany) during the period of about 1950 to 1985 may provide an interesting example regarding the produced and sold cars-though the efficiency gains in car motors were large in the western part, these gains were not used for reducing consumption but to increase consumption i.e., of car fuel and therefore emissions.) However, almost all authors agree that if the rebound can be proven, the policy implications would be severe: "One certain conclusion, though, is that if Jevons is right, then efficiency policies are simply counter-productive" [50] (p. 19).

\subsection{The Elaborate Rebound Circuit for Transportation}

When discussing the general Jevons paradox principle for the specific case of transportation, it comes to mind that besides the influencing factors of population, affluence or economic wealth as well as technology driving energy demand (see i.e., [53] (p. 346)), the specific factor of "globalization" is missing. Therefore, this additional factor is included in the control circuit for showcase reasons (see Figure 9), indicating at least two additional influencing directions:

(a) "Globalization" understood ceteris paribus as an increased volume of international trade as well as an increased average length of global supply chains due to labor specialization and division (i.e., more companies and country locations are included in producing the same product or service) leads on the one hand to an increased demand for raw materials as well as transportation services (bottom left-hand side of Figure 9). This is an additional influence, leading to an even stronger effect in the already increased demand for raw materials and transportation services (indicated with the blue highlighted increasing arrow).

(b) On the other hand, globalization understood as the increasing number of countries and companies taking part in international trade leads also to an increased competition in all markets (raw materials, finished goods as well as services, e.g., transportation), again influencing the rebound control circuit for transportation in the position of "decreased price for raw material as well as services"-and again, in this position the already existing effect of the Jevons paradox (decrease) is even enhanced by this additional competition through globalization.

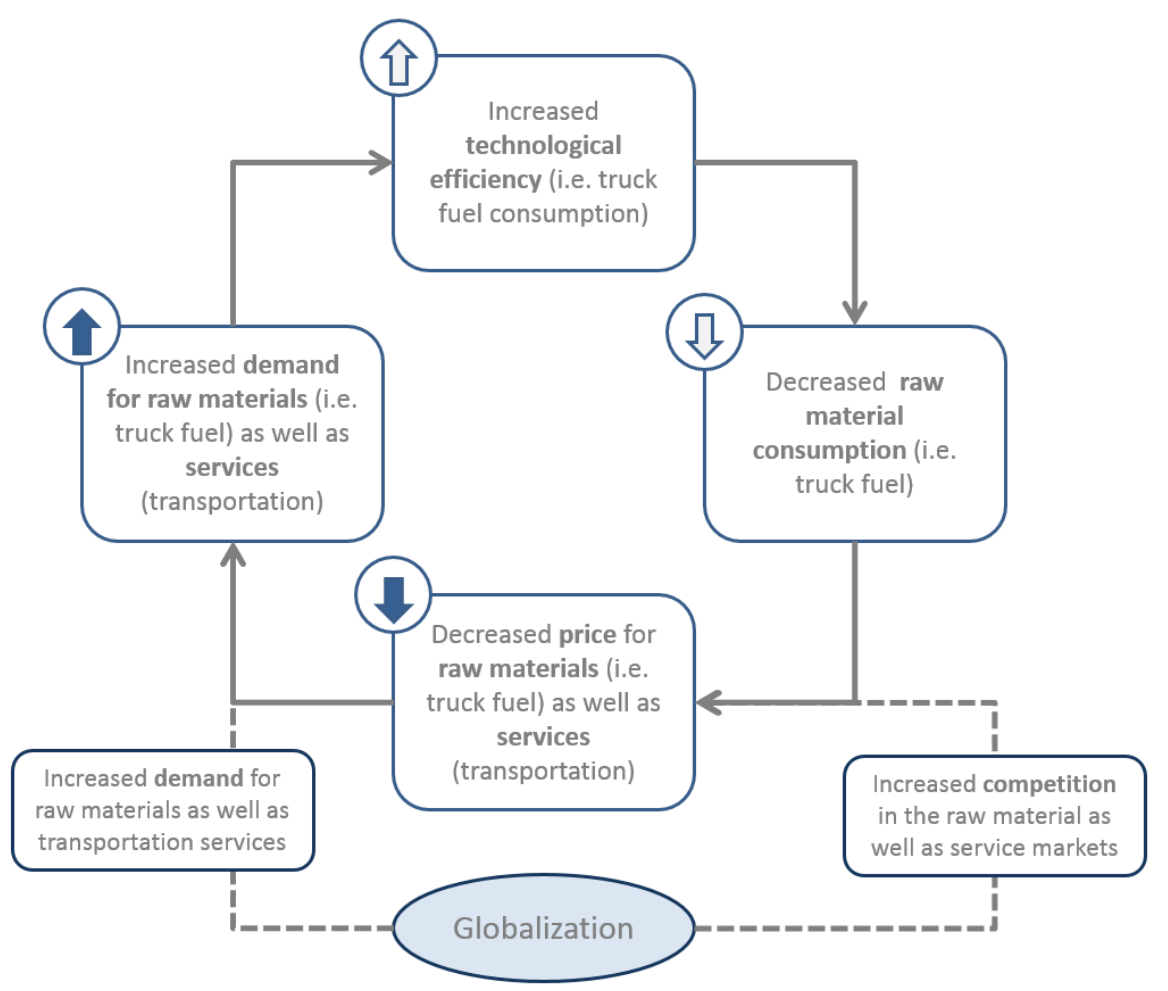

Figure 9. Elaborate transportation rebound circuit. 
This shows that the existing rebound effect may even be stronger for the real-life situation of transportation in a globalizing economy. Many scholars have tried to express the rebound effect in the form of an equation, i.e., for the variables $E$ as energy consumption or intensity, $P$ as population-or in some cases population growth $-A$ for affluence or GDP per capita as well as $T$ for technology or energy rate per GDP [53] (p. 346):

$$
\mathrm{E}=\mathrm{PAT} \text {, }
$$

in order to approximate the effects in transportation, the additional effect of globalization and increased international division of labor as well as trade volumes and distances has to be incorporated. For this, a current version of the rebound equation split up into four equations is used, depicting the established functional interdependence of the individual factors [49] (p. 1462):

$$
\begin{aligned}
& \mathrm{E}=f\left(\mathrm{P}, \mathrm{A}, \mathrm{T} ; \mathrm{X}_{\mathrm{E}}\right), \\
& \mathrm{P}=g\left(\mathrm{E}, \mathrm{A}, \mathrm{T} ; \mathrm{X}_{\mathrm{P}}\right), \\
& \mathrm{A}=h\left(\mathrm{E}, \mathrm{P}, \mathrm{T} ; \mathrm{X}_{\mathrm{A}}\right), \\
& \mathrm{T}=i\left(\mathrm{E}, \mathrm{P}, \mathrm{A} ; \mathrm{X}_{\mathrm{T}}\right) .
\end{aligned}
$$

A new extended and specified version of the equation system including the endogenous impact of globalization and trade increase may be suggested with $V$ as the global trade volume as quantitative indicator for globalization as follows:

$$
\begin{aligned}
& \mathrm{E}=f\left(\mathrm{P}, \mathrm{A}, \mathrm{T}, \mathrm{V} ; \mathrm{X}_{\mathrm{E}}\right), \\
& \mathrm{P}=g\left(\mathrm{E}, \mathrm{A}, \mathrm{T}, \mathrm{V} ; \mathrm{X}_{\mathrm{P}}\right), \\
& \mathrm{A}=h\left(\mathrm{E}, \mathrm{P}, \mathrm{T}, \mathrm{V} ; \mathrm{X}_{\mathrm{A}}\right), \\
& \mathrm{T}=i\left(\mathrm{E}, \mathrm{P}, \mathrm{A}, \mathrm{V} ; \mathrm{X}_{\mathrm{T}}\right) . \\
& \mathrm{V}=j\left(\mathrm{E}, \mathrm{P}, \mathrm{A}, \mathrm{T} ; \mathrm{X}_{\mathrm{V}}\right) .
\end{aligned}
$$

Within this system of equations it is obvious that an expected reduction of energy use $(E)$ over time is very unlikely as the only factor leading to possible decreases is $T$, whereas the other factors $P$, $A$ and $V$ are increasing and therefore leading in general to an increased overall energy consumption. Combined with the core of the Jevons paradox that technology and efficiency improvements influence the other factors positively in addition to the general interaction of factors, it can be assumed that overall energy consumption decreases by transportation are very unlikely; such scenarios may happen only in very rare situations as e.g., experienced during the 2008/2009 global economic crisis with quickly shrinking levels of affluence as well as global trade $(A, V)$. Such situations are (i) unlikely to happen regularly in the future and (ii) are not intended by politics and societies alike, as stated in the 2011 EU White Paper for transportation: "Curbing mobility is not an option" [62] (p. 5).

\subsection{Implications for Green Logistics}

The outlined interactions and consequences of the rebound effect for transportation may have at least the following consequences for green logistics on a business as well as an economic and policy level: 
(a) For individual logistics service providers, an increased sustainability efficiency (i.e., carbon emissions per tonkilometer) will usually not lead to overall absolute reductions in emissions, depending on the overall business volume development. This can be recognized in many company sustainability reports in the logistics industry, i.e., by the German DHL: DHL has increased the overall efficiency (carbon emissions per tonkilometer) by 7\% (base: 2007) from 2013 to 2014-nevertheless, the overall absolute carbon emission rose from 28.31 (2013) to 28.56 million tons in 2014, mainly due to an increased total transport volume but also caused by the extremely high share of air cargo of 63\% [63] (pp. 100, 109).

(b) For the national as well as global economic development it becomes obvious that increased globalization and trade will inevitably lead to higher transport and energy consumption levels. Under current physical conversion and primary energy use regimes, this will also lead to increasing absolute carbon emission levels.

(c) For transportation policy, this indicates that new approaches are necessary if green transportation and a reduction of carbon emissions from the transportation sector are really the objective for future policy implementation.

\section{The Median Voter and Time-Distorted Voter Preferences in Transportation Policy}

This section is enlarging the analysis to the political and social field of political decisions in interaction with voter demands and preferences. Regarding green logistics, the field of transportation and traffic policies in general is addressed. According to the median voter theorem [64,65], politicians will rationally align their implemented policies with the view of the median voter in order to guarantee a majority vote or acceptance (i.e., a majority share of votes in the next upcoming election). Therefore, policies regarding green logistics and transportation-i.e., with a higher taxation on emissions from traffic and transportation or other measures for supporting a modal shift or even a reduction in traffic-have to face the test of consumer and voter preferences. Otherwise, no rationally acting politician would be found to support and put such policies to a vote nor support their implementation.

\subsection{General Insights in Consumer and Voter Preferences Regarding Green Transportation}

Basically, two important consumer and voter characteristics are intertwined and are at play in the field of green transportation:

First, all consumers are also affected by changes in transport policies and regimes via their consumer role in passenger transport. For example, cost increases via taxes for road or rail transportation will affect them personally when travelling by car or public rail transport. Therefore, the voter preference structure will tend heavily towards lesser taxation or regulation than possibly necessary for a real sustainable development in transportation.

Second, people have largely time-distorted as well as place-distorted preferences: Rationally, consumption and wellbeing today and in the personal environment is valued higher than the future. This leads to massive rejection of traffic restrictions and taxation today, incurring future transport and ecological cost tomorrow due to impacts of climate change, traffic jams or other feedback loops. Furthermore, in traffic and transportation politics, also the place-distortion is hugely important: According to the "St. Florian Principle," people prefer external burdens like traffic routes to be placed away from their own vicinity, as far away as possible. This affects infrastructure projects as can be seen today in Germany, for example, with major rejection of much-needed electricity pathways from north to south in order to sustain the renewable energy boom network-wise. Though everybody supports green electricity from wind energy in general, single voters and consumers do not want to be affected by the specific burden of having an electricity line running through their neighborhood. This leads also to obstructions for planned railway lines which could enable a favorable modal shift in cargo transportation.

Both characteristics regarding voter and consumer preferences lead to a very restricted field of possible action and support in transportation politics, especially regarding sustainability-which will 
per definition restrict consumption and transportation today in order to sustain possible transport capacity in the future ("future generations" according to Brundtlandt).

\subsection{The Example of German Truck Toll Policy}

The German truck toll was introduced in 2005 based on a highly elaborate system with automatic GPS recognition of individual trucks. Besides very questionable political decisions regarding the operating private business consortium, a more recent decision will be analyzed for our research into green transportation policy: On 1 October 2015 for the first time since introducing the truck toll system, trucks with total payloads between 7.5 and 12 tons have to pay the toll too [66] (see Table 3). Historically, from the start, trucks up to 12 tons were exempt from the taxation system. Now, arguably in enlarging the income base for the toll system, the German political leadership has decided to enlarge the tolled truck fleet.

Table 3. Truck toll amounts in Germany from 1 October 2015 [67].

\begin{tabular}{ccccc}
\hline Category & Axles & Toll Share Emissions & Toll Share Infrastructure & Toll Total (£ Cent) \\
\hline A & 2 & 0 & 8.1 & 8.1 \\
$($ EURO VI) & 3 & 0 & 11.3 & 11.3 \\
& 4 & 0 & 11.7 & 11.7 \\
& $5+$ & 0 & 13.5 & 13.5 \\
\hline B & 2 & 2.1 & 8.1 & 10.2 \\
$($ EURO V /EEV) & 3 & 2.1 & 11.3 & 13.4 \\
& 4 & 2.1 & 11.7 & 13.8 \\
& $5+$ & 2.1 & 13.5 & 15.6 \\
\hline C & 2 & 3.2 & 8.1 & 11.3 \\
$($ EURO IV) & 3 & 3.2 & 11.3 & 14.5 \\
& 4 & 3.2 & 11.7 & 14.9 \\
& $5+$ & 3.2 & 13.5 & 16.7 \\
\hline D & 2 & 6.3 & 8.1 & 14.4 \\
$($ EURO III $)$ & 3 & 6.3 & 11.3 & 17.6 \\
& 4 & 6.3 & 11.7 & 18.0 \\
& $5+$ & 6.3 & 13.5 & 19.8 \\
\hline E & 2 & 7.3 & 8.1 & 15.4 \\
(EURO I/II) & 3 & 7.3 & 11.3 & 18.6 \\
& 4 & 7.3 & 11.7 & 19.0 \\
& $5+$ & 7.3 & 13.5 & 20.8 \\
\hline
\end{tabular}

This has severe and, as will be shown, negative consequences for green logistics and transportation:

(i) First, from a business investment perspective, a large write-down of fleet business values has to be acknowledged since a large share of the last-mile and distribution truck fleet was specifically bought with an 11.99-ton payload to avoid the toll while still transporting as much payload as possible. This even led to the emergence of a new weight class of trucks, not existent before. Now all these investment calculations are void and logistics businesses have to face a significant write-down of corporate value regarding the truck fleet between 7.5- and 12-ton payloads-which is economically highly unsustainable and furthermore an undermining of general business trust in politics. 
(ii) Second, transport companies may further use the same trucks with up to 12 tons of total payload but try to avoid the tolled streets (in Germany: motorways and four-lane highways), which will lead to longer transportation routes and therefore more travelled kilometers per shipment as well as higher emission volumes. This is clearly a negative consequence regarding sustainability as emissions per shipment will increase. Additionally, this will prevent the objective of internalization of external costs (road infrastructure, injuries, environmental impact) strived for in sustainability concepts as individual corporations may be forced to align their individual profit maximization with social cost and improvement objectives.

(iii) Third, as an alternative choice, logistics service providers may choose to soon replace the trucks with new, still toll-free trucks below 7.5 tons of total payload. This again will lead to a very negative effect on transportation-based emissions: As the same amount of shipments and shipment weights have to be transported, the average emission level per tonkilometer will increase. This is based on the physical fact that the share of cargo payload to total weight of the truck is increasing with size- and also the fact that fuel consumption is largely dependent on aerodynamic drag and not so much on total weight. For example, a 7.5-ton truck may transport about 2.5 tons with a fuel consumption of about 17-18 litres-whereas a 40-ton truck may transport about 25 tons of cargo payload with a fuel consumption of about 35 litres. Therefore, the smaller the truck, the more emissions per payload and shipment. Alas, also this third option means logistics companies are faced with comes with a negative effect on transport sustainability.

Altogether it has to be judged that the short-sighted incremental political decision to enlarge the truck toll fleet range by total weight has very huge and negative sustainability consequences. A better political concept would have been to legislate a mandate for an enlargement of the truck toll to all total weight classes (or even with increasing toll rates for smaller trucks as the above-depicted range for emission classes in Table 3 is still very small and ineffective) for about $5-10$ years down the road (i.e., 2025). This would have left the companies with sufficient time to adapt and invest in sustainable truck fleets. But the median voter and politicians' explanation models prevent such rational concepts because this regulation would be debated for the whole timeframe of anticipation; politicians thus aim for fast implementation. On the other hand, as implementation is some years ahead, the same politicians expect to not be the ones to profit from the increased toll income but rather their successors-which is not sufficient motivation to implement such ideas.

\subsection{The Policy Example of Electric Vehicles and Trucks}

A second example can be recognized in the political initiatives and programs regarding electric vehicles: Though scientifically the sustainability advantage of electric cars and trucks is highly questionable and, for the case of Germany, definitively negative (due to the specific electricity mix with a large share of coal-based electricity production, even increasing carbon emissions by electricity production due to the exit from nuclear electricity production), politicians still put money into supportive programs based on e-cars and e-trucks. This shows in addition to a specific lobbying success that politicians aim to "show off," explaining to voters that they are doing something about climate change and green transportation-knowing that the average voter will not understand the complex scope of the three carbon balance sheets for necessary electricity production.

This is not negating the fact that there are local advantages of electric cars and trucks (less noise, less emissions locally) - but the global sustainability balance is dependent on the electricity production mix and, in countries like Germany (and China, also investing heavily in electric transportation) with a high share of coal, this energy mix is negative. This again is the median voter model at work: Politicians are looking for easy-to-communicate solutions to generally acknowledged problems of society-though such easy solutions are increasingly seldom as especially global sustainability interactions increase.

There is no easy-to-fix solution for this voter and politician interaction problem regarding green transportation. The only viable improvements may come from increased transparency, increased communication from science towards the general public (honestly pointing at such problems and not 
primarily looking for further research funding), as well as increased education and knowledge for the general population. From the median voter model, the future expectation is that, with the increased education and access to information of the median voter (for at least half of the population), politicians and policies may follow this enhanced and informed view.

\section{What to Do About It: Possible Routes for Green Logistics and Green Transportation Policy}

Though the outlined facts and concepts behind the current history of green logistics may look bleak compared to the expectations and the policies required for facing and fighting climate change, there are possible ways forward. It has to be recognized that technological improvements are feasible and the "How to do it?" question is not so much the problem. The more important problem is the "How to implement it?" question; it is hence more or less a policy question in combination with business actors in logistics. But as outlined in the previous section, individual actors (industry, logistics service providers, consumers) mainly need clear and especially long-term framework regulations in order to act individually as well as in a socially efficient manner, also in the sustainability domain. (This notion can be traced back to the "invisible hand" propagated by Adam Smith already in 1776 -and we can assume it still holds today.) Though as the chapter on transportation from the IPCC report (2007) describes it, not much hope can be put into sheer price signals and taxation as the road to governmental action:

"While transport demand certainly responds to price signals, the demand for vehicles, vehicle travel and fuel use are significantly price inelastic. As a result, large increases in prices or taxes are required to make major changes in GHG emissions" [19] (p. 326).

As outlined above, such high taxation as is probably necessary is not popular with voters and therefore is not a viable option for rational policies and politicians. Also, many diversion and side effects are to be expected from any tax and pricing regimes in transportation $[68,69]$. Alas, two other roads towards a significant decrease in energy use and emissions from the transportation sector are explored below in order to provide an indication as to how even rational policies could implement real change for a green logistics and transportation future.

\subsection{Supply Side Restrictions and Management of Raw Materials}

One option may be the strict curbing of carbon primary energy like coal, oil and gas. As the international sources for these energy sources are limited, a tight control and rationing may be an option, though expectations for success may be limited due to negative experiences i.e., with the OPEC cooperation, to reach such an objective. Individual actors such as the EU, the US or China may complement this with an increased (and, as previously outlined, at best a known gradual increase over a longer period) customs taxation for inbound carbon primary energy. Though hard to implement politically, especially a long-term strategy with a gradual increase of taxation or restriction levels (e.g., as previously experienced with other products such as textiles) the market would be perfectly suited for an increase in technology development and use it to adjust to this restriction. Thus, for example, if a major player like the EU, US or China would ration the carbon primary energy import (on a decreasing level), prices may rise but not so steeply over the long term since technology adaption will allow for a larger decrease in specific consumption.

Therefore, such a solution may bring a real absolute reduction of carbon emissions, also from the transportation sector, without too much (though maybe some) restrictions to transportation. In any case, the necessary innovation may be supported and spurred in a long-term perspective. According to the political analysis outlined before, this way forward may still be problematic and "politically inaccessible," due to voter rejection and also prohibitive cooperation necessities among states ("prisoner's dilemma"). Therefore, a further productive way is outlined in the next section. 


\subsection{Supply Side Investment and Public Provision of Transportation or Fuel}

In the past and indeed since the publications of Adam Smith, it was an established paradigm that the public, hence the state, shall provide infrastructure as the central task for supporting a free market economy. Though until today many combination and cooperation models also with private and near-market provisions for public transport infrastructure such as toll systems and private management of motorways, rail tracks as well as sea and air routes have been implemented, still the majority vote goes for a dominantly public provision of transportation infrastructure. This is a second option for significantly improving the sustainability of transportation and logistics, with the burden of large investments needed to green the public infrastructure as a basis for greener transportation and logistics systems in the day-to-day business. All solutions will have to integrate future information-based services and options [70]. Chances of economic development depend heavily on such solutions as, otherwise, economic growth and wealth may be restricted [71]. Specifically, public provision of green transportation may come about in two forms:

(a) For rail- and network-based services, the state may provide the network infrastructure (as done today in many ways, by paying for the railway networks, etc.). This could be undertaken in a sustainable way, as, for example, the state producing and providing renewable energy for electrified railway tracks. This would have to happen at market-bearable costs or even at subsidized cost levels in order to support a modal shift from truck to rail transport.

(b) For individual transportation i.e., road or sea, there might be an option for a publicly provided supply of biofuels. This has to be within the parameters of second-generation biofuels such as hydrogen produced from a renewable energy like wind energy. Also, the price would have to be heavily subsidized to be competitive with fossil fuels, at least for a start phase of 15 to 20 years. This has been performed successfully e.g., within the German renewable electricity production system from solar and wind sources. This could work in a productive and complementary manner to the first option of restricting or taxing carbon primary energy as then the subsidized price of the biofuels would not have to be so high-i.e., expensive for the taxpayer.

Both described provisions will necessitate a long-lasting and costly engagement of public policy and budgeting towards green transportation. In this way, however, there may be a real option for reducing absolute energy consumption and emissions from transportation in spite of growing transport volumes and alongside increased technological efficiencies.

\section{Conclusions}

This article has analyzed the reasons for the current failure of green logistics by drawing on political, economic and business as well as social motivations and examples. This analysis has used the theorems of the Jevons paradox and the median voter in combination with time- and place-distorted preferences of voters and consumers. Therein it was shown with two cases from Germany that completely reducing energy consumption and emission levels from transportation in the face of growing trade and transportation volumes and despite increased technological efficiency is very difficult. However, the article proposed two encouraging ways forward: public restriction or heavy taxation of carbon raw materials (coal, oil, gas); and public investment in low-emission transport infrastructure and biofuels as the more viable and likely alternative. Especially the second provision would be able to serve as a guiding principle for political concepts and actions in the arena of green logistics in order to avoid the outlined negative effects of the Jevons paradox in the elaborated form discussed in the article. Therefore, there are implementation options that still enable the objectives of green logistics to be attainable in the future.

Acknowledgments: The author extends his gratitude to two anonymous reviewers for their valuable comments on the manuscript.

Conflicts of Interest: The author declares no conflict of interest. 


\section{Abbreviations}

The following abbreviations are used in this manuscript:

$\begin{array}{ll}\text { EU } & \text { European Union } \\ \text { GDP } & \text { Gross Domestic Product } \\ \text { GHG } & \text { Greenhouse gases } \\ \text { HD } & \text { Heavy duty } \\ \text { ICE } & \text { Internal combustion engine } \\ \text { IPCC } & \text { Intergovernmental Panel on Climate Change } \\ \text { LCA } & \text { Life-cycle assessment } \\ \text { US } & \text { United States } \\ \text { USA } & \text { United States of America }\end{array}$

\section{Appendix A}

Appendix A contains diesel consumption rates for HD trucks from test results in Germany since 2010. The average consumption is at $36 \mathrm{~L}$ with significant deviations by suppliers and models.

Table A1. Truck fuel consumption on German test road circuit since 2010 [37].

\begin{tabular}{|c|c|c|c|}
\hline Truck Model & EURO Emission Level & $\begin{array}{l}\text { Fuel Consumption in } \\
\text { Litre per } 100 \mathrm{~km}\end{array}$ & $\begin{array}{l}\text { Additive (Adblue) Consumption } \\
\text { in Litre per } 100 \mathrm{~km}\end{array}$ \\
\hline Volvo FH 500 Globetrotter & $\mathrm{V}$ & 36.4 & 1.96 \\
\hline Scania R 730 LA Topline & $\mathrm{V} / \mathrm{EEV}$ & 38.8 & 2.70 \\
\hline Mercedes Axor 1843 LS & $\mathrm{V}$ & 36.7 & 1.85 \\
\hline MAN TGX 18.400 XLX & $\mathrm{V}$ & 35.9 & 1.50 \\
\hline Scania G 420 LA Highline & $\mathrm{V}$ & 35.5 & 1.84 \\
\hline Mercedes Actros 1860 LS MP2 & $\mathrm{V}$ & 38.1 & 2.25 \\
\hline DAF XF 105.510 SuperSpacec. & $\mathrm{V}$ & 36.4 & 1.55 \\
\hline Renault Magnum 520 & $\mathrm{~V}$ & 36.7 & 2.00 \\
\hline Scania R 480 LA Topline & VI & 35.7 & 1.33 \\
\hline Iveco Stralis 460 Eco & V/EEV & 35.7 & 1.79 \\
\hline Volvo FH16-750 Globetr. XL & V/EEV & 39.0 & 2.03 \\
\hline Scania R 500 Highline Evolut. & V/EEV & 36.7 & 1.84 \\
\hline Mercedes Actros 1845 LS BS & VI & 35.1 & 1.14 \\
\hline DAF XF 105.460 te Spacecab & $\mathrm{V} / \mathrm{EEV}$ & 35.9 & 1.80 \\
\hline Renault Premium 430 Eco & V/EEV & 35.8 & 1.94 \\
\hline Scania G440 LA Highline & VI & 36.1 & 1.18 \\
\hline Mercedes Actros 1842 LS 2.3 & $\mathrm{~V} / \mathrm{EEV}$ & 34.3 & 1.65 \\
\hline Mercedes Actros 1842 LS G & VI & 35.3 & 0.90 \\
\hline Mercedes Actros 1842 LS 2.5 & VI & 34.8 & 0.80 \\
\hline MAN TGX 440 XLX & VI & 35.9 & 0.85 \\
\hline Iveco Stralis AS 440 S46 T HW & VI & 34.8 & 2.33 \\
\hline Scania G 410 LA Highline & VI & 32.9 & 2.14 \\
\hline Average & & 36.02 & \\
\hline
\end{tabular}

\section{Appendix B}

The following table describes the HD truck emission classes and their emissions for Europe. 
Table B1. Truck emission classes in Europe (g/kWh) [42].

\begin{tabular}{ccccc}
\hline Emission Class Regulation & CO & HC & NO $_{\mathbf{x}}$ & PM \\
\hline EURO I (1992) < 85 KW & 4.5 & 1.10 & 8.0 & 0.612 \\
EURO I (1992) > 85 KW & 4.5 & 1.10 & 8.0 & 0.360 \\
EURO II (1996) & 4.0 & 1.10 & 7.0 & 0.250 \\
EURO II (1998) & 4.0 & 1.10 & 7.0 & 0.150 \\
EURO III (2000) & 2.1 & 0.66 & 5.0 & 0.100 \\
EURO IV (2005) & 1.5 & 0.46 & 3.5 & 0.020 \\
EURO V (2008) & 1.5 & 0.46 & 2.0 & 0.020 \\
EURO VI (2013) & 1.5 & 0.13 & 0.4 & 0.010 \\
\hline
\end{tabular}

\section{References}

1. Von Carlowitz, H.-C. Sylvicultura Oeconomica; Johann Friedrich Braun: Leipzig, Germany, 1713.

2. Meadows, D.H.; Meadows, D.L.; Randers, J.; Behrens, W.W. The Limits to Growth; Universe Books: New York, NY, USA, 1972.

3. Meadows, D.H.; Meadows, D.L.; Randers, J. Beyond the Limits: Confronting Global Collapse, Envisioning a Sustainable Future; McClelland and Stewart: Toronto, ON, Canada, 1992.

4. Turner, G.M. A comparison of The Limits to Growth with 30 years of reality. Glob. Environ. Chang. 2008, 18, 397-411. [CrossRef]

5. Levallois, C. Can de-growth be considered a policy option? A historical note on Nicholas Georgescu-Roegen and the Club of Rome. Ecol. Econ. 2010, 69, 2271-2278. [CrossRef]

6. Brundtlandt, G.M. Our Common Future; World Commission on Environment and Development: New York, NY, USA, 1988.

7. Dijkema, G.P.J.; Ferra, P.; Herder, P.M.; Heitor, M. Trends and opportunities framing innovation for sustainability in the learning society. Technol. Forecast. Soc. Chang. 2006, 73, 215-227. [CrossRef]

8. Formentini, M.; Taticchi, P. Corporate sustainability approaches and governance mechanisms in sustainable supply chain management. J. Clean. Prod. 2016, 112, 1920-1933. [CrossRef]

9. Hussain, M.; Khan, M.; Al-Aomar, R. A framework for supply chain sustainability in service industry with Confirmatory Factor Analysis. Renew. Sustain. Energy Rev. 2016, 55, 1301-1312. [CrossRef]

10. Akhtar, P.; Tse, Y.K.; Khan, Z.; Rao-Nicholson, R. Data-driven and adaptive leadership contributing to sustainability: Global agri-food supply chains connected with emerging markets. Int. J. Prod. Econ. 2015. [CrossRef]

11. Hansen, T.; Coenen, L. The geography of sustainability transitions: Review, synthesis and reflections on an emergent research field. Environ. Innov. Soc. Trans. 2015, 17, 92-109. [CrossRef]

12. Vermeulen, W.J.V.; Witjes, S. On addressing the dual and embedded nature of business and the route towards corporate sustainability. J. Clean. Prod. 2016, 112, 2822-2832. [CrossRef]

13. McManners, P.J. Developing policy integrating sustainability: A case study into aviation. Environ. Sci. Policy 2016, 57, 86-92. [CrossRef]

14. Stas, D.; Lenort, R.; Wicher, P.; Holman, D. Green Transport Balanced Scorecard Model with Analytic Network Process Support. Sustainability 2015, 7, 15243-15261. [CrossRef]

15. Oltean-Dumbrava, C.; Watts, G.; Miah, A. Towards a more sustainable surface transport infrastructure: A case study of applying multi criteria analysis techniques to assess the sustainability of transport noise reducing devices. J. Clean. Prod. 2016, 112, 2922-2934. [CrossRef]

16. Zheng, Y.; Liao, H.; Yang, X. Stochastic Pricing and Order Model with Transportation Mode Selection for Low-Carbon Retailers. Sustainability 2015, 7, 15243-15261. [CrossRef]

17. European Commission, Eurostat. Transport in Figures 2015; Eurostat: Luxembourg, Luxembourg, 2016.

18. German Traffic Department (Bundesministerium für Verkehr). Verkehr in Zahlen 2015/2016; German Traffic Department: Berlin, Germany, 2016. 
19. Kahn Ribeiro, S.; Kobayashi, S.; Beuthe, M.; Gasca, J.; Greene, D.; Lee, D.S.; Muromachi, Y.; Newton, P.J.; Plotkin, S.; Sperling, D.; et al. Transport and its Infrastructure. In Climate Change 2007: Mitigation. Contribution of Working Group III to the Fourth Assessment Report of the Intergovernmental Panel on Climate Change; Metz, B., Davidson, O.R., Bosch, P.R., Dave, R., Meyer, L.A., Eds.; Cambridge University Press: Cambridge, UK; New York, NY, USA, 2007.

20. World Resources Institute. 6 Graphs Explain the World's Top 10 Emitters. Available online: http:/ /www.wri. org/blog/2014/11/6-graphs-explain-world\%E2\%80\%99s-top-10-emitters (accessed on 14 January 2016).

21. United States Environmental Protection Agency. Sources of Greenhouse Gas Emissions. Washington, 2016. Available online: http://www3.epa.gov/climatechange/ghgemissions/sources/transportation.html (accessed on 13 January 2016).

22. European Commission. Reducing Emissions from Transport. Brussels, 2016. Available online: http: / / ec.europa.eu/clima/policies/transport/index_en.htm (accessed on 14 January 2016).

23. Wang, N.; Yan, R. Research on Consumers' Use Willingness and Opinions of Electric Vehicle Sharing: An Empirical Study in Shanghai. Sustainability 2016. [CrossRef]

24. Hazen, B.T.; Overstreet, R.E.; Wang, Y. Predicting Public Bicycle Adoption Using the Technology Acceptance Model. Sustainability 2015, 7, 14558-14573. [CrossRef]

25. Hawrysz, L.; Foltys, J. Environmental Aspects of Social responsibility of Public Sector Organizations. Sustainability 2016, 8, 19. [CrossRef]

26. Klumpp, M.; de Leeuw, S.; Regattieri, A.; de Souza, R. Humanitarian Logistics and Sustainability; Lecture Notes in Logistics Series; Springer: Berlin, Germany, 2015.

27. Anten, N.; Ploos van Amstel, W.; Verweij, K. Lean and green: Creating a network community for sustainable logistics. In Proceedings of the Transport Research Arena (TRA) 5th Conference: Transport Solutions from Research to Deployment, Paris, France, 14-17 April 2014; Available online: http://www.bciglobal.com/ data/file/TRA2014_Fpaper_18265.pdf (accessed on 20 Januray 2016).

28. Gillis, D.; Semanjski, I.; Lauwers, D. How to Monitor Sustainable Mobility in Cities? Literature Review in the Frame of Creating a Set of Sustainable Mobility Indicators. Sustainability 2016, 8, 29. [CrossRef]

29. Tokunaga, K.; Konan, D.E. Home grown or imported? Biofuels life cycle GHG emissions in electricity generation and transportation. Appl. Energy 2014, 125, 123-131. [CrossRef]

30. Bergthorson, J.M.; Thomson, M.J. A review of the combustion and emissions properties of advanced transportation biofuels and their impact on existing and future engines. Renew. Sustain. Energy Rev. 2015, 42, 1393-1417. [CrossRef]

31. Deppermann, A.; Offermann, F.; Puttkammer, J.; Grethe, H. EU biofuel policies: Income effects and lobbying decisions in the German agricultural sector. Renew. Energy 2016, 87, 259-265. [CrossRef]

32. Lanzini, P.; Testa, F.; Iraldo, F. Factors affecting drivers' willingness to pay for biofuels: The case of Italy. J. Clean. Prod. 2016, 112, 2684-2692. [CrossRef]

33. The World Bank. Press Release: World Bank Lowers 2016 Forecasts for 37 of 46 Commodity Prices, Including Oil, 26 January 2016. Available online: http://www.worldbank.org/en/news/press-release/ 2016/01/26/world-bank-lowers-2016-forecasts-for-37-of-46-commodity-prices-including-oil (accessed on 27 January 2016).

34. NASDAQ. End of day Commodity Futures Price Quotes for Crude Oil WTI (NYMEX). Available online: http:/ / www.nasdaq.com/markets/crude-oil.aspx?timeframe=2y (accessed on 27 January 2016).

35. Eurotransport. Immer abwärts. Available online: http://www.eurotransport.de/news/lkwverbrauchswerte-von-1966-bis-2014-immer-abwaerts-6550678.html (accessed on 27 January 2016).

36. Eurotransport. Truck Diesel Consumption of Different Models on New Test Track Since 2010 [Verbrauch auf der neuen Teststrecke seit 2010]. Available online: http://www.eurotransport.de/news/1/9/8/5/8/4/9/ Verbrauch.pdf (accessed on 28 January 2016).

37. Gao, Z.; Smith, D.E.; Daw, C.S.; Edwards, K.D.; Kaul, B.C.; Domingo, N.; Parks, J.E., II; Jones, P.T. The evaluation of developing vehicle technologies on the fuel economy of long-haul trucks. Energy Convers. Manag. 2015, 106, 766-781. [CrossRef]

38. Shahraeeni, M.; Ahmed, S.; Malek, K.; Van Drimmelen, B.; Kjeang, E. Life cycle emissions and cost of transportation systems: Case study on diesel and natural gas for light duty trucks in municipal fleet operations. J. Nat. Gas Sci. Eng. 2015, 24, 26-34. [CrossRef] 
39. Li, W.; Dai, Y.; Ma, L.; Hao, H.; Lu, H.; Albinson, R.; Li, Z. Oil-saving pathways until 2030 for road freight transportation in China based on a cost-optimization model. Energy 2015, 86, 369-384. [CrossRef]

40. Thijssen, R.; Hofman, T.; Ham, J. Ecodriving acceptance: An experimental study on anticipation behavior of truck drivers. Transp. Res. Part F 2014, 22, 249-260. [CrossRef]

41. EU: Heavy-Duty: Emissions. Available online: http://transportpolicy.net/index.php?title=EU:_Heavy-duty: _Emissions (accessed on 28 January 2016).

42. German National Registration Department [Kraftfahrtbundesamt]. Truck Fleet on 01 January 2015 Regarding Emission and Weight Classes [Bestand an Nutzfahrzeugen am 1 January 2015 nach Fahrzeugklassen und Emissionsgruppen]. Available online: http://www.kba.de/SharedDocs/Publikationen/DE/Statistik/ Fahrzeuge/FZ/2015/fz13_2015_pdf.pdf?_blob=publicationFile\&v=2 (accessed on 28 January 2016).

43. European Commission. Roadmap to a Single European Transport Area. Available online: http://ec.europa. eu/transport/strategies/facts-and-figures/all-themes/index_en.htm (accessed on 28 January 2016).

44. European Expert Group on Future Transport Fuels. Future Transport Fuels Report January 2011. Available online: http:/ /ec.europa.eu/transport/themes/urban/cts/doc/2011-01-25-future-transport-fuels-report. pdf (accessed on 28 January 2016).

45. Mwangi, J.K.; Lee, W.; Chang, Y.; Chen, C.; Wang, L. An overview: Energy saving and pollution reduction by using green fuel blends in diesel engines. Appl. Energy 2015, 159, 214-236. [CrossRef]

46. Van Keulen, T.; van Mullem, D.; de Jager, B.; Kessels, J.T.B.A.; Steinbuch, M. Design, implementation, and experimental validation of optimal power split control for hybrid electric trucks. Control Eng. Pract. 2012, 20, 547-558. [CrossRef]

47. Jevons, W.S. The Coal Question: An Inquiry Concerning the Progress of the Nation, and the Probable Exhaustion of Our Coal Mines, 3rd ed.; Flux, A.W., Ed.; Kelley: New York, NY, USA, 1906.

48. Madlener, R.; Alcott, B. Energy rebound and economic growth: A review of the main issues and research needs. Energy 2009, 34, 370-376. [CrossRef]

49. Sorrell, S. Jevons' Paradox revisited: The evidence for backfire from improved energy efficiency. Energy Polily 2009, 37, 1456-1469. [CrossRef]

50. Alcott, B. Jevons' paradox. Ecol. Econ. 2005, 54, 9-21. [CrossRef]

51. Polimeni, J.M.; Mayumi, K.; Giampietro, M.; Alcott, B. The Myth of Resource Efficiency: The Jevons Paradox; Earthscan: New York, NY, USA, 2008.

52. Hanley, N.; McGregor, P.G.; Swales, J.K.; Turner, K. Do increases in energy efficiency improve environmental quality and sustainability? Ecol. Econ. 2009, 68, 692-709. [CrossRef]

53. Polimeni, J.M.; Polimeni, R.I. Jevons' Paradox and the myth of technological liberation. Ecol. Complex. 2006, 3, 344-353. [CrossRef]

54. Clark, B.; Foster, J.B. William Stanley Jevons and the Coal Question. Organ. Environ. 2001, 14, 93-98. [CrossRef]

55. Greene, D.L. Vehicle use and fuel economy: How big is the rebound effect? Energy J. 1992, 13, 117-143. [CrossRef]

56. Wang, Z.; Lu, M. An empirical study of direct rebound effect for road freight transport in China. Appl. Energy 2014, 133, 274-281. [CrossRef]

57. Winebrake, J.J.; Green, E.H.; Comer, B.; Corbett, J.J.; Froman, S. Estimating the direct rebound effect for on-road freight transportation. Energy Policy 2012, 48, 252-259. [CrossRef]

58. Lin, B.; Liu, X. Reform of refined oil product pricing mechanism and energy rebound effect for passenger transportation in China. Energy Policy 2013, 57, 329-337. [CrossRef]

59. Matos, F.J.F.; Silva, F.J.F. The rebound effect on road freight transport: Empirical evidence from Portugal. Energy Policy 2011, 39, 2833-2841. [CrossRef]

60. Myrdal, G. Economic Theory and Underdeveloped Regions; Duckworth: London, UK, 1957.

61. Fujita, N. Myrdal's Theory of Cumulative Causation. Evolut. Inst. Econ. Rev. 2007, 3, 275-283. [CrossRef]

62. European Commission. White Paper: Roadmap to a Single European Transport Area-Towards a Competitive and Resource Efficient Transport System; European Commission: Brussels, Belgium, 2011.

63. Deutsche Post DHL Group. Corporate Social Responsibility Report 2014; Deutsche Post DHL AG: Bonn, Germany, 2015.

64. Downs, A. An Economic Theory of Political Action in a Democracy. J. Political Econ. 1957, 65, $135-150$. [CrossRef] 
65. Black, D. On the Rationale of Group Decision-making. J. Political Econ. 1948, 56, 23-34. [CrossRef]

66. Lohre, D.; Schwichtenberg, M. Auswirkungen der Mautänderungen 2015 auf die Abwicklungskosten bei Stückgutverkehren; Hochschule Heilbronn: Heilbronn, Germany, 2015.

67. Toll Collect. Toll Charges for Trucks in Germany from 1st of October 2015. Available online: https://www. toll-collect.de/de/toll_collect/rund_um_die_maut/maut_tarife/maut_tarife_2015.html (accessed on 31 January 2016).

68. Luechinger, S.; Roth, F. Effects of a mileage tax for trucks. J. Urban Econ. 2016, 92, 1-15. [CrossRef]

69. Solaymani, S.; Kardooni, R.; Yusoff, S.B.; Kari, F. The impacts of climate change policies on the transportation sector. Energy 2015, 81, 719-728. [CrossRef]

70. Miller, H.J. Beyond sharing: Cultivating cooperative transportation systems through geographic information science. J. Transp. Geogr. 2013, 31, 296-308. [CrossRef]

71. Sorman, A.H.; Giampietro, M. The energetic metabolism of societies and the degrowth paradigm: Analyzing biophysical constraints and realities. J. Clean. Prod. 2013, 38, 80-93. [CrossRef]

(C) 2016 by the author; licensee MDPI, Basel, Switzerland. This article is an open access article distributed under the terms and conditions of the Creative Commons Attribution (CC-BY) license (http://creativecommons.org/licenses/by/4.0/). 